\title{
Alterações cromossômicas e freqüência do rearranjo gênico BCR/ABL ao diagnóstico, tratamento com mesilato de imatinibe e após transplante de medula óssea em leucemia mielóide crônica

\author{
Chromosomal alterations and frequency of the BCR/ABL gene rearrangement at diagnosis of \\ chronic myeloid leukemia, treatment with imatinib mesylate followed by bone marrow \\ transplantation
}

Cristina B. Vendrame-Goloni

Orientadora

Agnes C. Fett-Conte

\section{Resumo}

A leucemia mielóide crônica (LMC) é uma doença mieloproliferativa clonal que surge da transformação neoplásica das células progenitoras pluripotentes, resultando em uma granulocitose progressiva. É um protótipo de câncer desencadeado por uma alteração cromossômica específica, a t(9:22) que origina o cromossomo Philadelphia $(\mathrm{Ph})$. Essa translocação resulta na formação de um gene quimérico $B C R / A B L$.

O presente trabalho teve como objetivos investigar as alterações cariotípicas ao diagnóstico da LMC, com o uso da técnica do bandamento GTG, estudar a presença e a freqüência do rearranjo gênico $B C R / A B L$ ao diagnóstico, durante o tratamento com mesilato de imatinibe e após o transplante de medula óssea, com o uso da técnica de hibridação in situ fluorescente (FISH). Também, com base na freqüência de $B C R / A B L$, avaliar o tempo para aquisição da remissão citogenética completa, a sobrevida livre de doença após o TMO e a taxa de mortalidade relacionada a este procedimento, além de avaliar a resposta citogenética dos pacientes em uso exclusivo do mesilato de imatinibe e investigar as exposições ocupacionais dos pacientes, para tentar correlacionar tal exposição com possíveis agentes etiológicos da LMC.
Foram estudadas 145 amostras de medula óssea de 66 indivíduos portadores de LMC. A análise por citogenética convencional foi realizada somente nos casos encaminhados ao diagnóstico antes de qualquer tipo de tratamento e a análise por FISH foi realizada em todos os casos.

$\mathrm{O}$ cromossomo $\mathrm{Ph}$ e o rearranjo $B C R / A B L$ foram observados em $100 \%$ dos casos analisados ao diagnóstico com as diferentes técnicas. A freqüência do cromossomo $\mathrm{Ph}$ detectado por bandamento GTG foi mais alta do que do rearranjo, porém a técnica de FISH foi mais eficaz na estimativa das freqüências in vivo e possibilitou a identificação de alterações inespecíficas envolvendo os genes $B C R$ e/ou $A B L$.

Dos 24 pacientes submetidos ao TMO, 79,2\% atingiram remissão citogenética completa, 37,5\% desses até 60 dias após o transplante, um tempo indicativo de melhor prognóstico. A sobrevida global foi de $70,8 \%$ e a sobrevida livre de doença variou de 11 a 72 meses. A taxa de mortalidade relacionada ao transplante foi de $29,2 \%$. Estes dados foram compatíveis com os previamente descritos.

Para os pacientes tratados com imatinibe, 28,6\% não apresentaram o rearranjo $B C R / A B L$, sugerindo resposta citogenética completa, $25 \%$ apresentaram freqüência alta do rearranjo e $21,4 \%$ apresentaram o rearranjo associado com outras alterações envolvendo $B C R$ e $A B L$. Os resultados mostraram que essas outras alterações não parecem estar relacionadas com resistência à droga, pois ocorreram em freqüências baixas e não puderam ser relacionadas com a resposta citogenética ou com o tempo de tratamento.

A resposta ao mesilato de imatinibe foi boa na maioria dos casos. Parece ser individual e imprevisível, independente da fase de início e do tempo de tratamento com a droga.

Trabalho de tese de doutorado desenvolvido no Laboratório de Genética do Depto. de Biologia Molecular.

Faculdade de Medicina de São José do Rio Preto (Famerp) - São José do Rio Preto-SP - Brasil.

Correspondência para: Cristina B. Vendrame-Goloni

Hemocentro - Laboratório de Genética

Av. Brigadeiro Faria Lima, 5544 - Bairro Universitário

15090-000 - São José do Rio Preto-SP - Brasil

Tel.: (017) 3201-5000 R. 1931

E-mail: cristina.benitez@ig.com.br 
As técnicas de bandamento GTG e FISH foram fundamentais para a obtenção dos resultados e foram complementares, portanto, devem ser utilizadas na análise de pacientes com LMC.

Palavras chave: Leucemia mielóide crônica; mesilato de imatinibe; rearranjo gênico $B C R / A B L$.

\section{Abstract}

Chronic myeloid leukemia (CML) is a clonal myeloproliferative disease which emerges from a neoplastic transformation of the pluripotent stem cells, resulting in a progressive granulocytosis. It is a prototype for cancer triggered by a specific chromosomal alteration, $\mathrm{t}(9: 22)$ which originates the Philadelphia $(\mathrm{Ph})$ chromosome. This translocation results in the formation of a $B C R / A B L$ chimeric gene.

This work aimed at investigating the karyotypic alterations at diagnosis of CML using GTG banding and studying the presence and the frequency of the $B C R / A B L$ gene rearrangement at diagnosis, during treatment with imatinib mesylate and after bone marrow transplantation, using the Fluorescence in situ hybridization method (FISH). Additionally, the frequency of the $B C R / A B L$ rearrangement was used to evaluate the time to reach complete cytogenetic remission, the disease-free survival rate after bone marrow transplantation and the procedure-related mortality rate, as well as to assess the cytogenetic response of patients to the exclusive use of imatinib mesylate and investigate the occupational exposure of patients, to attempt to correlate the exposure to possible etiological agents with CML.

One hundred and forty-five samples of bone marrow from 66 individuals suffering from CML were studied. Conventional cytogenetic analysis was only performed in the cases received at diagnosis, that is before any type of treatment and FISH analysis was carried out in all cases.

The $\mathrm{Ph}$ chromosome and the $B C R / A B L$ rearrangement were identified in all the cases analyzed at diagnosis by the different techniques. The frequency of the Ph chromosome detected by GTG banding was higher than the rearrangement however, the FISH technique was more efficacious in the estimates of in vivo frequencies and enabled the identification of unspecific alterations involving the $B C R$ and $A B L$ genes.

Of the 24 patients submitted to bone marrow transplantation, $79.2 \%$ achieved complete cytogenetic remission, $37.5 \%$ of whom within 60 days of transplantation, a time indicative of better prognosis. The overall survival rate was $70.8 \%$ and the disease-free survival varied from 11 to 72 months. The transplant-related mortality rate was $29.2 \%$. These data were similar to previously published results.

For patients treated with imatinib, 28.6\% did not present with the $B C R / A B L$ rearrangement, suggesting complete cytogenetic response, $25 \%$ presented with a high frequency and $21.4 \%$ presented with the rearrangement associated with other alterations involving the $B C R$ and $A B L$ genes. The results demonstrated that these other alterations do not seem to be related with drug resistance as they occurred at low rates and could not be related to cytogenetic response or to the time of treatment.

The response to imatinib mesylate was good in the majority of cases. It seems to be individual and unpredictable, independent of the initial phase and of the length of treatment using the drug.

The GTG banding and FISH techniques were essential to obtain the results and were complementary and thus should be used in he analysis of patients with CML.

Key words: Chronic myeloid leukemia; $B C R / A B L$ gene rearrangement; imatinib mesylate.

Avaliação: A Revista Brasileira de Hematologia e Hemoterapia publica os resumos e abstracts de teses da área apresentados em universidades que tenham programas de pós-graduação reconhecidos pelo MEC/ Capes e considere a obtenção do título suficiente para sua publicação na forma como se propõe a seção.

Recebido: 13/07/2003

Aceito após modificações: 15/08/2004 